\title{
Differences in stomatal number per unit area within the same species under different micro-environmental conditions: A working hypothesis
}

\author{
Eduardo Lleras (")
}

\begin{abstract}
A summary of Salisbury's (1927) work on stomata is presented here. He found, basically, that the number of stomata per unit area increased under more xerophytic conditions. This is contrary to prevalent opinion, that postulates that under more humid conditions, the number of stomata can be greater, as there is less danger of dehydra tion. A hypothesis is presented here that can explain this: The more xerophytic the conditions, the higher the number of stomata per unit area to permit more efficient gas interchange at those times when relative humidity is high, and danger of excessive dehydration is lowest.
\end{abstract}

Stomata are one of the most studied plant structures, as is obvious by the large number of papers published on the subject each year.

In spite of the great amount of work done on stomata, little or no attention has been paid until recently (except for occasional references in the literature) to the variation in stomatal numbers within the same species. In fact, in a majority of cases, stomatal number are usually assumed to be fairly constant within certain limits, and are cited as such (eg. Kramer \& Kozlowski, 1960; Ormrod \& Renney, 1968). If differences are observed, they are usually atributed to varietal and clonal (genetic) factors (eg. Heichel, 1971).

In 1927, Salisbury did a thorough survey of stomata of woodland flora in Great Britain. He studied over 300 species, and found striking differences in stomatal frequencies within the same species, and even in the same individual, depending on microenviromental conditions. Unfortunately, Salisbury's work is largely unknown (or has been ignored) by a large majority of researchers working with stomata.

I am, therefore, going to present here a brief summary of his work, as it basically supports my own and my students findings in our research on stomata.
Salisbury notes that there is a negative correlation between number of stomata and leaf area. He also notes that there is a frequency gradient in stomatal numbers associated with height above the ground, and correlates this greater exposure of the leaf the higher the level at which it is borne. The higher the ieaf, the greater the number of stomata per unit area (Fig. 1, - A, B, C, D, E).

He also observed that in postrate plants, there was no gradient between basal and apical leaves. He noted that It would appear then from the observed facts, that the frequency gradient associated with increasing height above the ground is correlated with the greater degree of exposure to which the leaf is subject the higher the level at which it is borne.
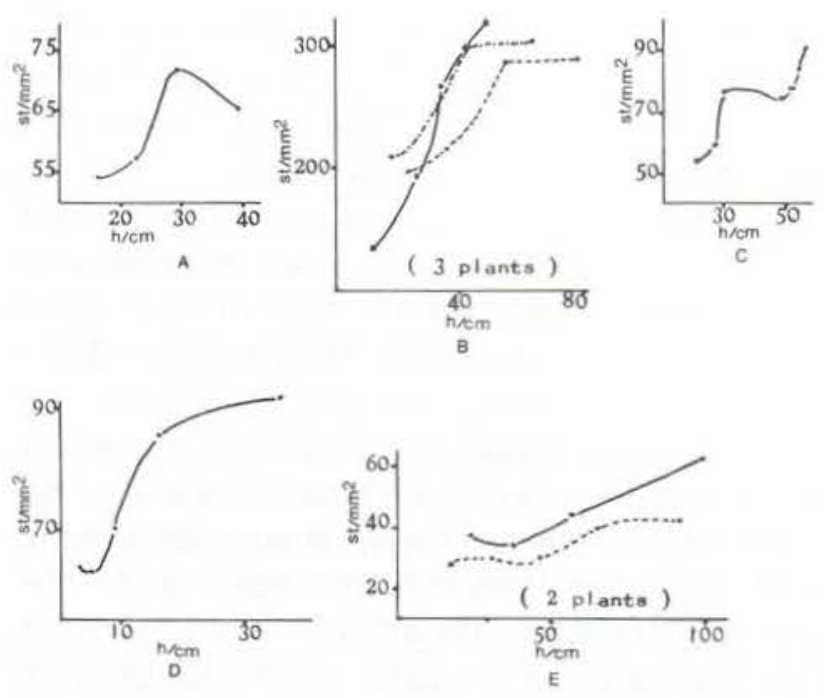

Fig. 1 - Relationship between number of stoma$\mathrm{ta} / \mathrm{mm}^{2}$ and height above the ground in 5 species of plants of the British flora. (Adapted from Salisbury, 1927). A, Holcus mollis; B, Brachypodium sylvaticcum; C, Polygonatum multiflorum; D, Hor. deum sylvaticum; E, Festuca gigantea.

(*) - Instituto Nacional de Pesquisas da Amazônia, Manaus. 
Salisbury then compared plants of the same species grown under wet and dry conditions. $\mathrm{He}$ found that while plants grown in dry condition presented the expected gradients in stomatal numbers between basal and apical leaves, the gradient disappeared when the plants were grown under humid conditions. Thus, he further concluded that the humidity of the internal and external environments of the leaf are the controling factors in determining the numerical frequency of its stomata.

He then studied the differences in stomatal numbers on different parts of the same leaf. $\mathrm{He}$ found that stomatal numbers per unit area were lower towards the base than towards the apex and middle of the same leaf. (Fig. 2, A, $B, C, D)$. Also observed was the fact that stomatal numbers were higher towards the margins, and lower towards the mid-rib. From this he concluded that stomata decreased in number as the distance to the vascular system became smaller. For monocots, he observed that the apex and the base had significantly lower numbers than the middle of the leaf blade, noting that the first two were formed while protected by the leaf sheath, while the middle was formed exposed to the air by intercalary growth. He noted that conditions favouring high rates of transpiration or a low rate of water intake (e. g., distance from vascular supply) favour high stomatal frequencies.

Among other things, Salisbury also pointed out that there was no significant difference in number of stomata grown in light or dark, other conditions being the same. He also pointed out that the more xerophytic the conditions, the more stomatal frequency increases. He noted that Stomatal frequency cannot, therefore, be regarded as a means of adaptational adjustment with respect to transpiration checks" and, "the stomatal frequency has an important ecological significance as an indicator of the humidity of the environment. But, contrary to the accepted view, the correlation is negative and not positive, and has no adaptational significance in relation either to transpiration or assimilation.

This leaves us with a perplexing paradox: if we accept the "accepted view" (and unfortunately, it is still today prevalentiy accepted for example, Kramer \& Kozlowski, 1960) we would have to postulate that Salisbury's data
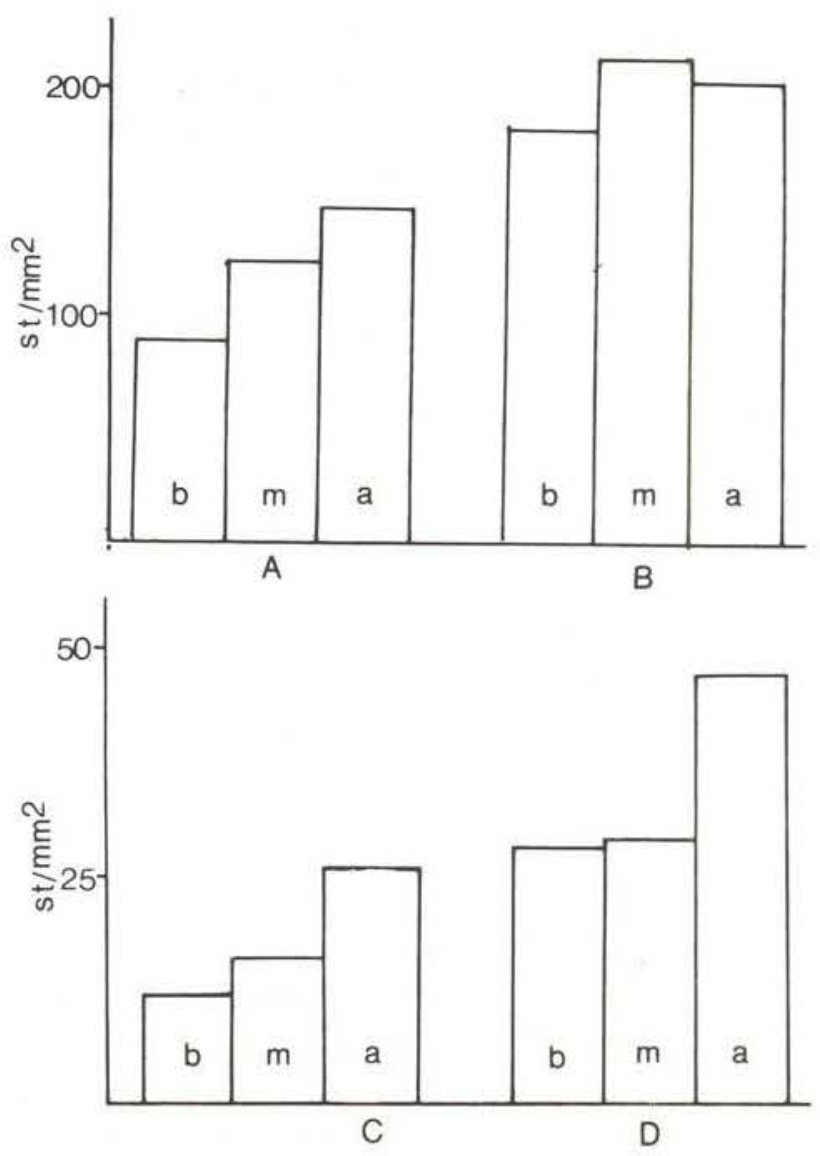

Fig. 2 - Differences in stomatal number on different parts of the leaf, $b$, base; $m$, middle; $a$, apex. A, Stellaria holostea; B, Scabiosa succisa; C, Alisma ranunculoides; D, Adoxa moschatellina (adapted from Salisbury, 1927).

are incorrect. This, I think, is not the case. In recent years we have gathered (and this will be amply shown in subsequent papers on leaf physiological ecology) ample proof as to the correctness of this observations. Thus, must we conclude (as is implicit in Salisbury's paper) that frequency of stomata is of negative adaptive value? We here present an alternate hypothesis that may explain why stomatal frequency is greater the more "xerophytic" the conditions.

First, we must establish the function of stomata. Stomata play important roles in both in gas interchange and in transpiration. Here, we will limit ourselves to a discussion of gas interchange, as transpiration will be the topic of other papers. It has been well established 
(eg. Kramer Kozlowșki, 1960) that stomatal transpiration is responsable from $85-95 \%$ of the total transpiration; we can postulate that it is responsable for aproximately the same percentages of gas interchange.

It has been shown that relative humidity plays an important role in the aperture and closure of stomata (Otto, 1969). It has also been shown that the degree of exposure drastically influences relative humidity (Kramer \& Kozlowski, 1960; Selleck \& Shuppert, 1957). Selleck \& Shuppert (1957) have shown that relative humidity remains significantly higher inside of a forest than in an adjacent open area during long periods each day. Hales (194S, cited in Selleck \& Shuppert, 1957), working in a tropical environment, found that the time, per day, in which a considerable difference in relative humidity could be observed often reached eight hours. Selleck \& Shuppert note, for temperate forests, times of 4-5 hours.

If we accept Otto's (1969) observation that the aperture of stomata is diréctly proportional to the relative humidity, stomata in plants exposed to conditions of low relative humidity during long periods of the day, maintain their stomata closed during most of the time. Thus, gas interchange cannot be realized during these periods.

The problem, now, is that leaves in "more xerophytic conditions" have less time (since their stomata are closed) for gas interchange, than leaves of the same species, be it in different plants or different parts of the same plant under more humid conditions.

It is here postulated, therefore, that the more xerophytic the conditions, the greater the frequency of stomata per unit area, to permit a more efficient gas interchange at those times when relative humidity is high and thus danger of excessive, dehydration is minimal.

It has been argued (Kramer \& Kozlowski, $1960)$ that relative humidity is not an adequate measure of the water stress that the plant (leaf) is subject to, and that this is best expressed with vapor pressure. The following graph, taken from data presented by Kramer \& Kozlowski, indicates that for all practical purposes, the two are interchangeable in expressing this stress:

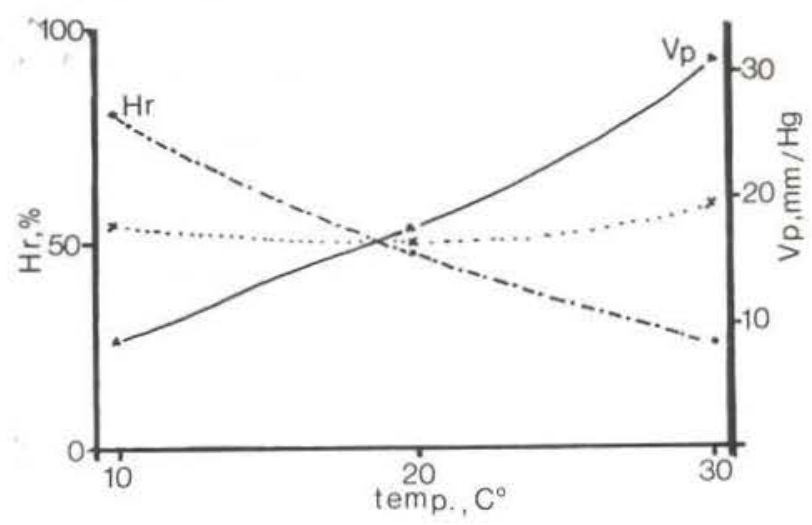

Fig. 3-Comparison of relative humidity (Hr) and vapor presure (Vp) with constant absolute humidity at various temperatures. (Plotted from data presented by Kramer \& Kozlowski, 1960). The dotted line at center expresses the degree of negative correlation between the two.

It is shown in this paper that much more research, as weli as a more comprehensive and critical review of past research must be carried out in order to adequately elucidate the mechanical aspects of stomatal functions. The validity of the above presented hypothesis is at present being tested with tropical plants, with very encouraging results.

\section{Resumo}

Apresenta-se aqui um resumo do trabalho de Salisbury (1927). Ele verificou que o número de estômatos por unidade de área aumenta quando as condiçōes são mais xerofíticas. Este resultado não está de acordo com as idéias "clássicas", que postulam que em condiçōes de maior umidade, o número estomático poderá ser maior sendo que há menor perigo de desidratação. Apresenta-se aqui uma hipótese que poderá explicar satisfatoriamente as observações de Salisbury. Quanto mais xerofíticas as condições, maior freqüência estomática por unidade de área. Assim, é permitida uma troca de gases mais eficiente nos períodos em que a umidade relativa é alta, quando o perigo de desidratação excessiva é mínimo.

\section{LITERATURE CITED}

HEICHEL, G.H.

1971 - Genetic Control of Epidermal Cell and Stomatal Frequency in Maize. Crop Sci., $11: 830-832$. 
KRAMER, P.J. \& KozLOWSKI, T.

1960 - Physiology of Trees. McGraw-Hill, New York. $740 \mathrm{p}$.

ORMROD, D.J. \& RENNEY, A.J.

1968 - A Survey of Weed Leaf Stomata and Trichomes. Can. Jour. Pla. Sci., 48 : 197-209.

Orto, H.W.

1969 - Plant Injury by Air Pollutants: Influence of Humidity on Stomatal Aperture and Plant Responses to Ozone. Science, $163: 1209-1210$.
SALISBURY, E.J.

1927 - On the Causes and Ecological Significance of Stomatal Frequency, with Special Reference to the Woodland Flora. Phil. Trans. Royal Soc. London, s.B, $216: 1-65$.

SElleck, G.W. \& SHuppert, K.

1957 - Some aspects of Microclimate in a Pine Forest and an Adjacent Prairie. Ecology, $38: 650-653$. 